\title{
Tissue Transglutaminase IgA Antibody Measurement
}

National Cancer Institute

\section{Source}

National Cancer Institute. Tissue Transg/utaminase IgA Antibody Measurement. NCI

Thesaurus. Code C147441.

The determination of the amount of tissue transg lutaminase $\lg \mathrm{A}$ antibody present in a sample. 